\title{
СУЧАСНЕ СТАВЛЕННЯ ДО УЧАСТІ МЕДИЧНИХ СЕСТЕР У ВИРІШЕННІ ПРОБЛЕМИ ЛІКУВАННЯ ПОСТРАЖДАЛИХ ВІД НАСЛІДКІВ АВАРІЇ НА ЧОРНОБИЛЬСЬКІЙ АТОМНІЙ ЕЛЕКТРОСТАНЦІї ТА МЕТОДОЛОГІї ДІАГНОСТИКИ ТА ЛІКУВАННЯ БОЛЮ У ЦІЁ̈ КАТЕГОРІЇ ХВОРИХ
}

\author{
О. Є. Шевченко, С. О. Ястремська \\ Луганська обласна лікарня № 2 \\ ДВНЗ «Тернопільський державний медичний університет \\ імені І. Я. Горбачевського МОЗ Украӥни» \\ ННI медсестринства
}

Біль, за визначенням Міжнародної асоціації з вивчення болю (IASP), це неприємне сенсорне і емоційне переживання, пов'язане з дійсним або потенційним пошкодженням тканини. Біль є однією з найпоширеніших скарг, проте являє собою феномен, найтяжчий для уточнення. Тривалий час він розглядався виключно як проблема лікаря і пацієнта, проте протягом останнього часу в боротьбі 3 ним значне місце стали займати медичні сестри. Для досягнення позитивного ефекту необхідно користуватись обгрунтованими стандартами та схемами діагностики і лікування.

\section{MODERN VIEWS ON THE PARTICIPATION OF NURSES IN ADRESSING THE TREATMENT OF VICTIMS FROM THE CONSEQUENCES OF THE CHORNOBYL NUCLEAR POWER PLANT ACCIDENT AND METHODOLOGY OF PAIN EVALUATION AND TREATMENT IN THESE PATIENTS}

\author{
O. Ye. Shevchenko, S. O. Yastremska \\ Luhanck Regional Hospital № 2 \\ SHEI "Ternopil State Medical University by I. Ya. Horbachevsky of MPH of Ukraine» \\ Educational and Scientific Institute of Nursing
}

International Association for the Study of Pain (IASP) gives the following definition of pain: it is an unpleasant sensory and emotional experience associated with actual or potential tissue damage. Pain is a common complaint, but this is a phenomenon most difficult to clarify. For a long time it was considered only as a problem of a doctor and a patient, but in the latest times nurses began to occupy an important place in fighting with it. However, the positive effect in that can be achieved only by using reasonable standards and schemes for pain evaluation and treatment.

Вступ. Актуальність обраної теми дослідження пов'язана з такими причинами: значним розповсюдженням захворюваності серед постраждалих від наслідків аварії на Чорнобильській атомній електростанціі (ЧАEC), переосмисленням участі медпрацівників, зокрема медичних сестер та са-

(C) О. Є. Шевченко, С. О. Ястремська, 2014 мих пацієнтів у вирішенні їх лікування, у тому числі больового синдрому.

Вивчення наслідків, пов'язаних із Чорнобильською аварією, показали, що вплив на організм постраждалих різних заінтенсивністюй тривалістю так званих малих доз іонізуючого випромінювання призвели до дуже своєрідних захворювань, які 
відрізняються широким спектром клінічних проявів соматогенного і психогенного характеру різних ступенів тяжкості.

Особливу увагу привертає до себе значне збільшення числа цереброваскулярної патології серед постраждалих, зокрема дисциркуляторних енцефалопатій через чутливість до різних додаткових екзогенних подразнювальних чинників, виснаження адаптивних резервів нервової системи, що майже завжди супроводжується цефалгічним синдромом, лікування якого стало значною проблемою.

За роки після аварії на ЧАЕС стало помітно, що пацієнти з числа постраждалих почали вимагати до себе посиленої уваги медичного персоналу і більш високого рівня комфорту, ніж хворі інших категорій. Причини такої вимогливості зумовлені, перш за все особливим статутом постраждалих, визначений у законі про їх соціальний захист, пільгамивідповідно до цього закону, що у повному обсязі ніколи не виконувала держава, високою, порівняно 3 іншим населенням, соціальною активністю даної категорії громадян щодо забезпечення чи відновлення наданих законом пільг, що призвело до їх постійного емоційного напруження, а це, у свою чергу, до розладів психогенного та іншого характеру. Цьому посприяли і такі негативні фактори, як ігнорування постраждалими здорового способу життя, шкідливі звички тощо [1-4].

Звісно, що усе це сприяло виникненню у постраждалих постійного душевного дискомфорту, тривоги, страху, болю найрізноманітнішого характеру. Проте згідно з висновками літературних джерел [5], добре підготовлений пацієнт набагато легше переносить вказані симптоми, особливо біль.

За даними ВОО3, за масштабами поширення біль можна порівняти з пандемією. Для вирішення проблеми болю виділено величезні кошти, й тільки в США створено понад дві тисячі клінік та центрів з його вивчення. Набув поширення термін «медицина болю». Конгрес США оголосив 20012010 рр. Декадою контролю над болем і науки про біль. Усвідомлення даної проблеми у суспільстві привело до створення спеціалізованих громадських організацій. Нині функціонують Міжнародна асоціація з вивчення болю (IASP), Європейська федерація (EFIC), Українська асоціація з вивчення болю (UASP), головний осередок якої розміщений на базі Луганської обласної лікарні № 2.
Тривалий час біль розглядався виключно як проблема лікаря і пацієнта. Проте протягом останнього часу у боротьбі з ним значне місце стали посідати медичні сестри. Нині середній медичний персонал став оволодівати все більш складними медичними, психологічними, технічними знаннями та навичками, йому добре знайоме поняття сестринського діагнозу, яке вперше було офіційно визнано і законодавчо закріплено в 1973 р. у США [6].

Основна частина. Біль, за визначенням Міжнародної асоціації з вивчення болю (IASP), це неприємне сенсорне і емоційне переживання, пов'язане з дійсним або потенційним пошкодженням тканини. $Є$ й інше визначення: біль - це психічний стан, що виникає в результаті надсильних або руйнівних впливів на організм при загрозі його існуванню або цілісності. Разом з тим, біль, це найцінніше набуття еволюції усього живого, у тому числі людини, який охороняє іï з моменту народження. Відчуття болю можуть варіювати від легкого до тяжкого, від тимчасового до постійного, класифікованого як гострий або хронічний і т. д.

Біль $є$ однією з найпоширеніших скарг, проте являє собою феномен, найтяжчий для уточнення.

Розглядаючи характеристики болю необхідно зазначити таке:

- біль може мати суб'єктивний характер і виникати без реального пошкодження чи порушення функції органа або системи;

- доки не існує методів для абсолютно об'єктивного оцінювання болю.

Зрозуміло, що через це виникають труднощі при діагностиці та лікуванні больового синдрому медичними сестрами [7], особливо у пацієнтів 3 числа постраждалих від наслідків аварії на ЧАЕС.

Звісно, що в процесі лікування позитивного ефекту можна досягнути лише користуючись обґрунтованими стандартами та схемами діагностики і лікування [8].

Отже, зупинимось на визначенні стандарту - це хворі, які страждають від хронічного чи гострого болю, що повинні отримати сестринську допомогу, спрямовану на усунення або полегшення цього симптому, щоб поліпшити якість життя кожного хворого.

Обґрунтування лікування. Як було зазначено вище, за масштабами поширення біль можна порівняти з пандемією. Дослідження ж показують, що полегшення болю може бути досягнуто у 85 \% хворих, бо досить часто хронічний біль - це комп- 
лекс переживань і відчуттів хворого, викликаний низкою причин, при цьому чуттєвий компонент (страх, занепокоєння, депресія) може мати значний вплив на стан і настрій хворого. Як відомо, принципи лікування болю визначаються механізмом захворювання, індивідуалізацією терапіі, прагненням уніфікувати тактику лікування. Під час оцінки болю у пацієнта збирається необхідна інформація, яка дозволяє планувати лікування. Біль симптом непостійний, а тому оцінка його повинна бути постійною. Сестринське співчуття і порада, поряд з фармакологічною дією медпрепаратів, часто полегшують біль, а роль медичної сестри може бути ключовою при переконанні хворого в можливості лікування болю. Контроль болю - обов'язок не тільки медичної сестри, у цьому потрібна тісна співпраця з колегами, іншими членами колективу, їх знання та досвід.

Які ж основні ресурси медсестри у боротьбі 3 болем?

Вона повинна:

- володіти базовими знаннями;

- оцінювати біль (з урахуванням фізичного та емоційного компонентів);

- використовувати карту обстеження за пізнанням болю;

- використовувати протибольові засоби, доступні у даному закладі;

- знати дозування аналгетиків;

- знати особливості болю у хворих із числа постраждалих від наслідків аварії на ЧАЕС;

- знати чинники, що позитивно чи негативно впливають на біль (занепокоєння, самотність, побутові чи соціальні негаразди, безсоння інше);

- знати, чи впливають фізичні та психологічні чинники на біль у конкретного хворого;

- знати, чи впливає біль на працездатність і соціальну активність постраждалого;

- бути обізнаною в сучасній медичній літературі 3 лікування болю;

- спілкуватися з хворим, членами його сім'ї, іншими медичними працівниками для ефективного лікування болю;

- проводити навчання хворого і членів його сім'ї, що стосуються причин і способів терапії болю та іх використання;

- володіти навичками мануальної терапії, масажу тощо;

- організовувати спостереження за хворими, проводити навчання з медсестрами відділень, де лікуються хворі з больовими синдромами;
- володіти детальними знаннями з проблеми болю, бути готовою консультувати персонал зі складних питань болю;

- у процесі лікування болю контактувати з іншими членами колективу, включно з фізіотерапевтами, голкорефлексотерапевтами тощо;

- впливати на створення нормального охоронного режиму у відділеннях;

- мати сприятливі умови для роботи як медична сестра.

Схема проведення протибольової допомоги:

- виявлення факторів, що впливають на біль, усунення їх за допомогою психологічних прийомів, зниження рівня занепокоєння, забезпечення адекватного сну, відволікання хворого іншими формами діяльності тощо;

- разом з лікуючим лікарем уточнювати призначення аналгетиків;

- надавати хворому необхідну інформацію про хід лікування.

Результат лікування болю:

- отримання достовірної інформації про те, що біль став слабшим, зник або залишився таким же чи став ще сильнішим;

- здійснення медичною сестрою відповідного запису в карті обстеження про результат лікування болю та інформування про це лікуючого лікаря.

Висновки. Оскільки має місце значне розповсюдження захворюваності серед постраждалих від наслідків аварії на Чорнобильській атомній електростанціі, готовність медичних сестер вирішувати проблеми лікування, у тому числі больового синдрому, робить цю тему надзвичайно актуальною та вимагає усвідомлення важливих фактів, а came:

- тривалий час біль розглядався виключно як проблема лікаря іпацієнта, проте протягом останнього часу в боротьбі з ним значне місце стали займати медичні сестри;

- біль залишається однією з найпоширеніших скарг, проте і найтяжчою для уточнення;

- у процесі лікування болю позитивного ефекту можна досягнути, користуючись обґрунтованими стандартами та схемамидіагностикиі лікування;

- біль є симптомом непостійним, що вимагає проведення його постійного та повторного оцінювання у пацієнта;

- сестринське співчуття і порада, поряд з фармакологічною дією медпрепаратів, сприяють полегшенню болю, роль медичної сестри може 
бути ключовою у переконанні хворого в можливості його лікування;

\section{ЛІТЕРАТУРА}

1. Порушення регуляції серцево-судинної і нервової системи у осіб, які постраждали від аварії на ЧАЕС, і використання фізичних факторів для їх корекції / В. М. Запорожан, Ю. Л. Курако, В. М. Юрлов, І. П. Шмакова / / Актуальні прогнозивніпорушення психологічного стану здоров'я після ядерної катастрофи в Чорнобилі : тези доповідей міжнародної конференції. -К., 1995. - C. 200-201.

2. ЗозуляЮ. А. Вплив малих доз іонізуючоїрадіаціїна головний мозок: структурні проявлення і діагностика / Ю. А. Зозуля, А. Р. Вінницький // Актуальні прогнозивні порушення психологічного стану здоров'я після ядерної катастрофи в Чорнобилі : тезидоповідей міжнародної конференції. - К., 1995. - С. 50-51.

3. Красиленко Е. П. Возрастнаядинамикацеребрального кровотока у ликвидаторов последствий аварии на ЧАЭС / Е. П. Красиленко // Врачебное дело. - 2002. - № 3-4. - C. 27-32.
- медична сестра повинна знати особливості болю у хворих із числа постраждалих від наслідків аварії на ЧAEC.

4. Клинические особенности мозговых инсупьтов у пиквидаторов последствий авариина ЧАЭС / Т. В. Мироненко, К. В. Торба, Н. Л. Пицуп [и др.] // Международный неврологическийжурнал. - 2007. - № 2 (12). - С. 39-47.

5. Артеменкова Н. Прийоми психотерапії та психокорекціі / Н. Артеменкова / / Сестринська справа. 2011 . - № 8. - C. 43, 48.

6. Каптач А. Пробпеми сестринської паліативної допомоги в Польщі / А. Каптач / / Медична сестра. 2011. - № 3. - С. 21, 23.

7. Глотова І. Г. Які знання потрібні практичній медсестрі? / І. Г. Глотова, О.М.Стрельникова / / Сестринська справа. - 2000. - № 1. - С. 9, 12.

8. Twycross R. Symptom Control in Advanced Cancer / R. Twycross, S. Lack : Pain Relief. London, 1983. 